\title{
The Norwegian Petroleum Regulatory Framework and the Transition to Green Energy
}

\begin{abstract}
Alexandru Gociu*
ABSTRACT The purpose of this article is to critically explore the history of the Norwegian petroleum regulatory framework to reveal the main legal innovations that spurred the creation of an original model focused on the principles of sustainability and environmental protection. I analyse how these principles facilitated the transition process from reliance on fossil fuels to the development of renewable sources of energy. After the discovery of oil, Norway, though inexperienced in petroleum exploration and exploitation, was able to coin a framework that kept control over the oil industry in the state's hands. The "go slow" policy and the creation of the national company were the main instruments to maintain a strong bargaining power in relation to big multinational oil companies. Norway enacted 10 "oil commandments" which formed the basis for its oil constitutionalism. This led to the principles of sustainability and environmental protection being codified in article 112 of the constitution in 1992 (as former Art 110 b). I will show how these unique conditions aided the transition to renewable sources of energy and compelled the national oil company, Statoil (now Equinor ASA), to invest and innovate in the field.
\end{abstract}

\section{Introduction}

Norway is one of the largest oil producers in the world, but an unconventional one as it has gradually transitioned to renewable sources of energy as a source of income instead of oil. This process has not been without controversy as the Norwegian legal system favours environmental protection and sustainable use of natural resources while also supporting its petroleum industry. In 2017 this conflict was publicised by an ice sculpture erected near the Oslo courthouse by environmental groups. The sculpture depicted article 112 of the Norwegian Constitution ${ }^{1}$ and

\footnotetext{
* PhD Candidate at School of Law, Trinity College Dublin, ORCID 0000-0002-0704-7050, email: gociua@tcd.ie. I would like to thank my esteemed supervisor, Assistant Professor Dr. Suryapratim Roy, for his invaluable support and guidance. My gratitude extends to the anonymous peer reviewers for their effort and time invested in reviewing my article offering me helpful suggestions and comments.

${ }^{1}$ Mikael Holter, 'Arctic Oil Drilling Under Attack As Norway Dragged To Court', (World Oil, 13 November 2017) $<$ www.worldoil.com/News/2017/11/13/Arctic-Oil-Drilling-Under-Attack-As-Norway-Dragged-To-Court> accessed 30 June 2020
} 
highlighted one of the most important judicial proceedings for future oil exploration in the Arctic. In this proceeding, a group of NGOs challenged the Norwegian Government' ${ }^{2}$ decision to grant oil exploration licenses in the Arctic. They relied on article 112 which guarantees natural resource sustainability and environmental protection. This was unprecedented for a nation with a reputation for environmental protection and sustainability.

This reputation is best demonstrated by the Storting's (Norwegian Parliament) response to the discovery of oil on the Norwegian Continental Shelf in the early 1960s. As a small nation lacking experience in oil and gas but with considerable expertise in hydropower, Norway enacted a revolutionary regulatory framework. Indeed, the seeds of sustainability and subsequent transition to renewable energy were planted by the Storting enacting the "10 oil commandments" in 1971. This legislation shaped Norwegian oil policy for decades by acting as an "oil constitution" which guided and shaped political decisions about oil. It also emphasized the importance of national control over oil and gas resources as well as ensuring a strong emphasis on sustainability. Furthermore, the "go slow" policy played a dual role to both enforce control over oil production and increase the Norway's bargaining power with big oil companies.

Given this unique regulatory environment, this article focuses on how Norway is transitioning to renewable sources of energy while still retaining abundant national deposits of oil and gas. Indeed, this approach which centralizes the regulation of oil exploitation is not only an effective transition to renewable energy but has not previously been analysed in depth and is thus, the legal nature of this transition is focus of this article. Section 2 traces the origins of Norwegian Oil Policy, namely the Norwegian hydropower regulation and the development of early petroleum regulation in the 1960s and early 1970s. The role of the global oil crisis and protectionist policies on oil supply will be discussed next. Section 3 focuses on Norwegian oil constitutionalism which includes the "10 oil commandments" that functioned as the world's first 'oil constitution', the creation of the national oil company, the "go slow" policy, and the principle of realist sustainability. It will be shown that Norwegian oil constitutionalism involves a long-term oil policy and a transition to domestic renewable sources of energy. Section 4 discusses the recent Supreme Court case of Norwegian People $v$ Arctic case where some of the primary tenets of oil

\footnotetext{
${ }^{2}$ Oslo District Court 16-166674TVI-OTIR/06, Borgarting Court of Appeal 18-060499ASD-BORG/03, Supreme Court of Norway HR-2020-846-J, (sak nr. 20-051052SIV-HRET).
} 
constitutionalism came to the fore. Lastly, the article argues that the entire Norwegian legal framework was developed under the banner of "realist sustainability" which favoured later the transition to renewable energy.

\section{The origins of Norwegian oil policy}

Norway designed its petroleum regulatory framework in an was unconventional manner given that oil and gas was approached on different grounds by other countries in the late 1960s Based on its hydropower experience Norway started to build slowly a petroleum regulatory framework that would keep oil and gas reserves under state control. This early regulation and the evolution of oil and gas policy was determinant in creating the settings for a slow process of shifting its oil industry towards renewables despite still having large oil reserves on The Norwegian Continental Shelf. This process was possible because of the principle of realist sustainability embedded in early oil and gas regulation, way before being elevated at constitutional level. Thus, only analysing the evolution of the early Norwegian oil and gas policy and regulation framework, one can understand the philosophy behind Norway's contemporary approach to sustainability, protection of the environment and shift towards renewables.

\subsection{Hydropower and early petroleum regulation}

From its early days of independence, Norway has actively invested in the least polluting, most sustainable, and cheapest source of energy at the time: hydroelectric power. Hydroelectric power plants were designed to sustain electrochemical and electrometallurgical industries which were heavily power intensive. ${ }^{3}$ Unfortunately, Norway had limited capital resources for building dams and plants. ${ }^{4}$ Thus, foreign investors, mainly from France and Germany invested in the necessary infrastructure. ${ }^{5}$ Unsurprisingly, the challenge to regulate and control foreign interests

\footnotetext{
${ }^{3}$ Svein Ivar Angell, 'Den historiske bakgrunnen for heimfallsinstituttet' (2006) 05/2006 Magma Econas Tidsskrift for Økonomi og Ledelse <www.magma.no/den-historiske-bakgrunnen-for-heimfallsinstituttet> accessed 27 February 2020.

${ }^{4}$ Knut Kjeldstadli (1994): Et splittet samfunn, Aschehougs Norgeshistorie, Oslo: Aschehoug: 39, jf. Angell, Svein Ivar (2002): Den svenske modellen og det norske systemet - Tilhøvet mellom modernisering og identitetsdanning $i$ Sverige og Noreg ved overgangen til det 20. hundreåret, Oslo: Det Norske Samlaget: 31 ff. cited by Svein Ivar Angell, 'Den historiske bakgrunnen for heimfallsinstituttet' (2006) 05/2006 Magma Econas Tidsskrift for Økonomi og Ledelse < www.magma.no/den-historiske-bakgrunnen-for-heimfallsinstituttet> accessed 27 February 2020. ${ }_{5}^{5}$ Paul Cleary, Trillion Dollar Baby-How Norway beat the Oil Giants and Won a Lasting Fortune (Biteback Publishing, 2016) 3.
} 
in Norway became considerable. ${ }^{6}$ Therefore the Storting enacted the first concession laws (konsesjonslovene also known as panic-laws or panikklover) in 1906 which aimed to ensure natural resources were Norwegian state property. ${ }^{7}$ The legislation was extended in 1909 by the adoption of the regulation of the use of natural resources ${ }^{8}$ and in 1917 by an industrial concession law. ${ }^{9}$ This legal framework ensured early on, that the Norwegian philosophy, which links sustainability to tightly controlled natural resources, was enshrined in law.

After the Second World War, Norway experienced a strong economic ${ }^{10}$ development. $^{11}$ The cheap and sustainable electricity produced by hydroelectric plants contributed decisively to the development of the power-intensive chemical industry. ${ }^{12}$ However the main source of Norwegian national income was the shipping industry. ${ }^{13}$ In the first eighteen years after the war, the Labour Party were in power ${ }^{14}$ and governed according to basic principles of sustainability. ${ }^{15}$ Long-term investments that would build a robust economy were the priority, even at the cost of delaying consumption. ${ }^{16}$

Further, the Suez Crisis from 1956-1957 led oil companies to consider the North Sea as an attractive zone for petroleum exploration. ${ }^{17}$ At the same time, Europe enjoyed an accelerated rate of industrial development, thus needing more cheap oil. ${ }^{18}$ In the late 1950 s, Norway's Geological

\footnotetext{
${ }^{6}$ ibid.

${ }^{7}$ Angell (n 3).

8 ibid.

${ }^{9}$ The Norwegian approach was ideologically based on David Ricardo's concept economic rent and the reinterpretation of his ideas by Henry George. Henry George, Progress and Poverty; an Inquiry into the Cause of Industrial Depressions and of Increase of Want with Increase of Wealth: The Remedy (AMS Press New York 1973).

${ }^{10}$ Angus Maddison, Phases of Capitalist Development (Oxford 1989) 177.

${ }^{11}$ Helge Ryggvik, 'A Short History of the Norwegian Oil Industry: From Protected National Champions to Internationally Competitive Multinationals’ (2015) Business History Review 89 3, 5

12 ibid 6.

13 ibid.

${ }^{14}$ Cleary (n 5) 6.

15 ibid.

16 ibid.

${ }^{17}$ Petter Nore 'The Norwegian state's relationship to the international oil companies over North Sea Oil 1965-75' (PhD thesis, Thames Polytechnic 1979) 6 Shell Oil and Gas from the North Sea( Shell Briefing Service, May 1972, revised August 1972) 4.

${ }^{18}$ Oystein Noreng, The Oil Industry and Government Strategy in the Noth Sea (Croom Helm London, The International Research Center for Energy and Development (ICEED) Boulder, Colorado 1980) 37.
} 
Survey was sceptical that there was oil in the North Sea, ${ }^{19}$ thus Norway initially avoided ${ }^{20}$ the ratification Convention on the Continental Shelf (hereinafter referred as 'the Convention') adopted at the United Nations' Conference on the Law of the Sea (24 February to 27 April 1958). ${ }^{21}$

The discovery in 1959 of the Groningen natural gas field in the Netherlands ${ }^{22}$ also shifted attention $^{23}$ towards the North Sea. ${ }^{24}$ The first exploratory drillings from 1961 on the Norwegian Continental Shelf indicated the presence of oil. ${ }^{25}$ A short time later, larger oil companies began to express interest in exploring the Norwegian Continental Shelf. Starting in the autumn of 1962 and until June 1963, six oil companies approached the Norwegian government with a desire to explore the Norwegian Continental Shelf. ${ }^{26}$

Similarly to Norwegian hydropower regulation, Norwegian petroleum activity was regulated to ensure independent decision making and that the State retained tight control over all oil and gas related activities. Norway was already self-sufficient from an energy ${ }^{27}$ point-of-view ${ }^{28}$, due to hydropower which satisfied almost all of Norway's energy needs. ${ }^{29}$ This meant that Norway was energy independent and contributed to its strong bargaining power with big oil companies. However Norway still wanted to attract investments in oil and consolidate its position in the North Atlantic Shelf.

To remain competitive and an attractive option for foreign companies performing exploratory activity necessary for identifying Norwegian oil and gas reserves, the Norwegian government allowed licensing seventy-eight blocks of potential oil deposits. ${ }^{30}$ The area included

\footnotetext{
${ }^{19}$ Cleary (n 5) 12.

${ }^{20} \mathrm{ibid}$.

${ }^{21}$ ibid 11. Norway ratified the Convention in 1971.

${ }^{22}$ Nore (n 17) 6.

${ }^{23}$ ibid.

${ }^{24}$ Cleary (n 5) 12.

${ }^{25}$ Irvin L White, Don E Kash, Michael a Charlock, Michael L Devine and R. Leon Leonard, North Sea Oil and Gas (University of Oklahoma Press, Norman, Oklahoma 1973) 3.

${ }^{26}$ Nore (n 17) 6.

${ }^{27}$ Ryggvik (n 11) 12.

${ }^{28}$ ibid.

${ }^{29}$ David B. Keto, Law And Offshore Oil Development: The North Sea Experience (Praeger Publishers 1978) 33.

${ }^{30}$ Cleary (n 5) 17.
} 
almost $20 \%$ of the Norwegian Continental Shelf ${ }^{31}$ (48 000 square kilometres) ${ }^{32}$. In comparison to British oil regulation, Norway allocated only half of the area licensed by the United Kingdom. ${ }^{33}$ This is the first sign of a prudent oil exploration approach. However, the reality was that Norwegians were unacquainted with the exploration and exploitation of oil, while the British acquired experience from various oil ventures around the world via the company British Petroleum (BP). Norway's experience in the oil industry was restricted to the building and the operation of oil tankers. ${ }^{34}$ Furthermore Norway had no previous experience ${ }^{35}$ in offshore oil ${ }^{36}$ which meant that only established foreign oil companies had the experience to operate on the Norwegian Continental Shelf. ${ }^{37}$ The foreign presence was dominant in the inexperienced Scandinavian country. ${ }^{38}$ Also lacking experts in oil taxation, Norway was forced to rely on Esso's representative to help outline the fiscal regulations ${ }^{39}$ which offered a strong advantage to oil companies. ${ }^{40}$ However, Norway accepted the situation as it forecasted substantial benefits from royalties and taxes after finding oil. $^{41}$

Norway's position was economically weak as it was a smaller country than the UK or the Netherlands. ${ }^{42}$ At the same time Norway needed as many foreign oil companies as possible to conduct exploratory works in order to maximize the chance of oil finding ${ }^{43}$ while desperately needing foreign currency. ${ }^{44}$ The initial royalty was substantially lower than what oil companies had predicted, $10 \%$. This was even lower than what the United Kingdom demanded from oil companies. ${ }^{45}$ In the beginning, Norway could not afford a radically innovative oil policy. ${ }^{46}$ Thus

\footnotetext{
31 ibid.

${ }^{32}$ The area covered almost everything south of the 60th parallel.

${ }^{33}$ Keto (n 29)31.

${ }^{34}$ Noreng (n 18) 38.

${ }^{35}$ Cleary (n 5) 18.

${ }^{36}$ Noreng (n18) 41.

${ }^{37}$ ibid.

${ }^{38}$ Ryggvik (n 11) 8.

${ }^{39}$ Cleary (n 5) 18.

${ }^{40}$ Om Skattlegging Av Undersjøiske Petroleumsforekomster [About taxation of subsea petroleum resources], Besl. O. [Law] no. 129 (1964-65).

${ }^{41}$ Ryggvik (n 11) 7.

${ }^{42}$ Ryggvik (n 11) 7 Cleary (n 5) 19.

${ }^{43}$ Cleary (n 5) 19.

44 ibid 18.

${ }^{45}$ Ryggvik (n 11) 7.

${ }^{46}$ Cleary (n 5) 21.
} 
the Government had to carefully balance the internal political pressure to acquire experience in the field of exploration and exploitation of offshore oil and a good share of the profit with the need to attract big oil companies. ${ }^{47}$ This balance was sought to be gradually operationalised by the National Petroleum Council (NPC).

In May 1968, the NPC was established as a 'high level advisory body' and a 'forerunner to a formal regulatory authority ${ }^{48}$ with competence in anything oil related. While the Industry Department raised the issue of government participation to the NPC in 1968, but Norway had no capital for oil exploration. ${ }^{49}$ In response, the NPC drafted a licensing provision to allow state participation only when a commercially viable discovery was made. ${ }^{50}$ On 10 December 1968 the Norwegian government empowered the NPC to represent the state in negotiations with oil companies regarding state participation. ${ }^{51}$ Government participation in the 1969 licensing rounds varied between $5 \%$ and $40 \%{ }^{52}$

However despite this, the Norwegian state still had neither expertise nor financial means to implement its government share. ${ }^{53}$ As foreign currency was urgently needed to finance the exploration of oil, the NPC sought to limit local companies from being the primary players. ${ }^{54}$ This was met with some resistance as prominent business personalities and the largest Norwegian company, Norsk Hydro, lobbied for greater participation of local companies. ${ }^{55}$ They wanted to be involved in the promising new opportunity. ${ }^{56}$ Notwithstanding, foreign companies had a strong presence as Phillips Petroleum obtained promising blocks. ${ }^{57}$ Minority Norwegian participation

\footnotetext{
${ }^{47}$ Noreng (n 18) 41.

${ }^{48}$ Cleary (n 5) 30.

49 ibid 30-31.

50 ibid 31.

51 ibid.

${ }^{52}$ Lind T, and Mackay G, Norwegian Oil Policies, (C Hurst \& Coy, London1980) 102-103.

${ }^{53}$ Cleary (n 5) 31.

${ }^{54}$ Ryggvik (n 11) 7.

55 ibid.

56 ibid.

${ }^{57}$ Cleary (n 5) 28.
} 
was present in twenty-one blocks. ${ }^{58}$ In contrast, the first concession round of the United Kingdom ${ }^{59}$ saw British companies present in 283 of 346 blocks. $^{60}$

Though the NPC used strategic policies that attracted finance and expertise, oil was not discovered in the Norwegian blocks for three years. ${ }^{61}$ In a historic moment, gas and pressurised oil was found on 15 September $1969 .{ }^{62}$ On 23 December 1969 Norway officially announced the discovery of the Ekofisk oil field. ${ }^{63}$ Due to technological and expertise limitations, the Norwegian contribution to Ekofisk was low, in 1975 attaining only 28\%. ${ }^{64}$ The local companies were left with activities requiring basic skills. ${ }^{65}$ Despite strong oversight and a coherent normative framework for building the oil industry, the supply system for the petroleum operations was a challenge for the architects of the Norwegian petroleum regulatory framework. Here, the political economy of oil supply shows the development of a protectionist drive, and the gradual transition to a 'Go Slow' oil constitutionalism.

\subsection{Protectionist policies and the global oil crisis}

The supply and service industry in offshore oil exploration and exploitation is essential as it provides the necessary materials, equipment, food for personnel and maintenance equipment for production. At the beginning of the oil and gas operations on the Norwegian Continental Shelf in the early 1970s, the big American oil companies (Esso, Mobil and Amoco) ${ }^{66}$ tried to impose a supply system based almost exclusively on American products. ${ }^{67}$ Additionally, the oil companies requested unrestricted market access not only for themselves but for their supply and service industry. ${ }^{68}$ In the UK, in order to mitigate the effects of American supply policy the "Full and Fair

\footnotetext{
${ }^{58}$ Ryggvik (n 11) 7.

59 ibid.

60 ibid 8.

${ }^{61}$ Cleary (n 5) 20.

62 ibid 26; Cleary's personal communication with Finn Sandberg, curator of the Norwegian Oil Museum, 25

September 2015.

${ }^{63}$ Cleary (n 5) 27.

${ }^{64}$ Storting Petroleumsundersøkelser Nord for 62. Breddegrad [Petroleumexploration north of 62nd latitude], (White Paper no. 57, 1978-1979) cited also by Ryggvik (n 11) 14.

${ }^{65}$ Paul C. Hallwood, Transaction Cost and Trade between Multinational Corporations: A Study of Offshore Oil Production (Boston, 1990) 73 cited also by Ryggvik (n 10) 14.

${ }^{66}$ After mergers Esso and Mobil became ExxonMobil and Amoco, British Petroleum (BP).

${ }^{67}$ Cleary (n 5) 32.

${ }^{68}$ ibid.
} 
Opportunity for UK Suppliers" was initiated but the oil companies succeeded to neutralize the project. ${ }^{69}$ However the situation was different in Norway, as there the oil companies were willing to generally comply with the Norwegian rules ${ }^{70}$ and specifically, the policy of procuring services and supplies form Norwegian companies. ${ }^{71}$ A protectionist drive first manifested itself in Norway when significant stakeholders in the Norwegian shipbuilding industry became interested in supplying the oil industry. They successfully lobbied and achieved the enactment of the 1972 Royal decree ${ }^{72}$ which helped the Government to force operators to increase Norwegian participation in the supply system.

However, this legislation which required foreign big oil companies to buy Norwegian equipment could only be effective if there was a national supply and service industry. ${ }^{73}$ The Norwegian entrepreneurs responded quickly ${ }^{74}$ in the field of offshore oil equipment ${ }^{75}$ and challenged the American monopoly in oil rig construction, business securing, in short time, a market share of around $20 \%{ }^{76}$ Being a shipbuilding country, Norway also benefited from a strong and innovative ${ }^{77}$ financing system created for ensuring the capital to supply shipyards ${ }^{78}$ which dramatically improved the shift to build oil equipment. ${ }^{79}$ Thus, there was a convergence of interests of the shipping industry and the political move to promote Norwegian companies in having a hold on the supply of oil. ${ }^{80}$ However, Norwegian oil was hit hard in the wake of the 1973 oil crisis because of the lack of an extended industrial base, the inability to market their products efficiently, poor communication between small companies, and the inability to manage bids for

\footnotetext{
69 ibid.

70 ibid 33; Department of State, Cable from Oslo to Washington, 18 of July 1975 stating that: "oil companies have generally been anxious to demonstrate their willingness to cooperate with the Norwegian government and to operate as good corporate citizens in Norway".

71 ibid 33; Department of State, Cable from Oslo to Washington, 18 of July 1975 said that: 'Government is understood now to be exerting real pressure to swing as much as possible of the business, especially big items, to Norwegian companies'.

${ }^{72}$ Royal decree of 8 Dec. 1972, $\$ 54$.

73 Ryggvik (n 11) 11.

74 ibid 12.

75 'The New Vikings' The Economist 26.07.1975 cited also by Cleary (n 4) 111.

${ }^{76}$ Cleary (n 5) 112.

${ }^{77}$ Ryggvik (n 11) 12 and Hanisch and Nerheim, Fra Vantro Til Overmot, 223

${ }^{78}$ ibid.

${ }^{79}$ Cleary (n 5)114 and Ryggvik (n 11) 12, 33.

${ }^{80}$ Cleary (n 5) 113.
} 
equipment and installations. ${ }^{81}$ In the United Kingdom, given the economic crisis and unemployment from the winter of 1974 that slowed down the British economy, the Labour government, led by Harold Wilson, started to mirror the Norwegian protectionist approach to eliminate Norwegians from the British market. ${ }^{82}$

Initially, American companies still were able to import a lot of American equipment for their platforms on the Norwegian Continental Shelf. ${ }^{83}$ While the rigs were constructed by Norwegians, these local companies lacked the advanced technologically capability for a complete operation of an offshore production unit. ${ }^{84}$ This meant that American companies such as Santa Fe, Rowan Companies, and Zapata were produced and operated ${ }^{85}$ in-house technology on Norwegianbuilt drilling rigs. ${ }^{86}$ However following the 1972 decree, Norwegians began to innovate at an astonishing pace. There were two dimensions of the Norwegian approach. The first was to adapt existing technologies to the special conditions of the North Sea, and the second was to develop new technologies that would facilitate a smooth and efficient operation. ${ }^{87}$ For example, one local business designed a new semi-submersible drilling rig to survive the rough conditions of the North Sea while also improving operability, seaworthiness, mobility, and cost efficiency. ${ }^{88}$

In addition to these technological advances, the Norwegian government also devised three regulatory innovations. Firstly, concession agreements ${ }^{89}$ were approved by both the Ministry of Petroleum and the Storting. The latter is significant because Parliamentary members are seated by regions not by party affiliation meaning that successful licensing bids require oil companies to boost businesses in different regions of Norway. Additionally, the 1972 decree meant that exploratory and development licenses were subject to oil companies "generat[ing] business for

\footnotetext{
${ }^{81}$ Noreng (n 18) 56.

${ }^{82}$ Ryggvik (n 11) 14.

${ }^{83}$ Cleary (n 5) 112.

${ }^{84}$ ibid 14.

${ }^{85}$ Carl-Axel Janicke, Oljeboring Til Havs: Historien Om En Ny Norsk Ncering [Offshore oil drilling: The story of a new Norwegian industry] (Oslo, 1984), 39 Ryggvik (n 11) 13.

${ }^{86}$ Ryggvik (n 11) 13.

87 ibid.

${ }^{88}$ Norsk Oljemuseum Oil and Gas Fields in Norway Industrial Heritage Plan 26. $<$ https://www.norskolje.museum.no/en/home/oil-facts/publications/oil-and-gas-fields-in-norway/> accessed 12 May 2021.

${ }^{89}$ Under concession agreements, a petroleum company or consortium carries out exploratory activities. The company gains ownership of all production, when extracted, against payment of a royalty to the host state.
} 
local companies". ${ }^{90}$ Secondly, the Government engaged in field development and indicated where pipelines should be installed and the requisite platform specifications. ${ }^{91}$ Third, the Norwegians capped state participation at $50 \%$ in promising oil fields which also boosted the Norwegian supply and service sector..$^{92}$

These regulatory innovations were destined mainly to serve as channels to impose increasingly stronger state control over petroleum activity and the creation, initially, of a strong Norwegian supply and service sector for the oil and gas activity on the shelf. Noticeable, as soon as Norway was able to increase its relevance in the oil technology field and imposed protectionist regulation (all this in a favourable international context) used its power to tighten furthermore the State's grip on the oil and gas industry. This process continued for a while allowing Norway to impose its own terms, not only in protecting Norwegian immediate economic interests, but also in requiring that oil and gas activity is conducted in a sustainable manner, with as little damage on the environment as possible.

However, in 1970 Middle Eastern oil supply caused concerns to western officials. ${ }^{93}$ OPEC $^{94}$ members unilaterally changed the terms of existing licenses ${ }^{95}$ as it led to contracting parties hardening the terms of licenses such as actively seeking nationalization of their oil industry. ${ }^{96}$. Moreover the Yom Kippur war determined the $\mathrm{OAPEC}^{97}$ to impose an oil embargo targeting countries that supported Israel. Thus, oil prices soared abruptly and in 1973-1974, an oil crisis emerged. ${ }^{98}$ Given this uncertainty and the proximity ${ }^{99}$ of the North Sea oil fields, oil

\footnotetext{
${ }^{90}$ Cleary (n 5) 33.

91 ibid 34.

92 ibid.

${ }^{93}$ Keto (n 29) 32.

${ }^{94}$ OPEC (Organization of the Petroleum Exporting Countries) was founded on 14 September 1960 in Baghdad by Iran, Iraq, Kuwait, Saudi Arabia, and Venezuela being destined to coordinate and unify the petroleum policies of its members and ensure the stabilization of oil markets.

${ }^{95}$ Kenneth W. Dam, Oil Resources - Who Gets What How? (The University of Chicago 1976) 61.

${ }^{96}$ Noreng (n 18) 47. The trend was started by Libya by renegotiating its concession agreements (Keto (n 33) 32).

${ }^{97}$ OAPEC (Organization of Arab Petroleum Exporting Countries) OAPEC Kingdom of Saudi Arabia, Kuwait and Libya in Beirut signed on January 9, 1968 the agreement for the creation of OAPEC aimed at Arab cooperation in the field of oil.

${ }^{98}$ Keto (n 29) 32.

${ }^{99}$ Ole Andreas H. Engen names it in 'The Development of the Norwegian Petroleum Innovation System: A Historical Overview'(2007) TIK Working Paper on Innovation Studies No. 20070605 University of Stavanger part
} 
companies were determined to develop North Sea oil as soon as possible. ${ }^{100}$ Indeed, the political stability of the region was certainly an attraction ${ }^{101}$ driven by seriatim economics for oil companies.

These were unique conditions for the Norwegian petroleum sector to develop and, given the international instability and the mounting pressure from oil companies to obtain oil from a predictable and stable democracy, the Norwegians faced an increasing demand for oil to counter the OPEC created crisis. This demand implied huge pressure to increase exploration and exploitation activity on the Norwegian Continental Shelf, and to increase forex earnings. Therefore, the Norway needed to innovate in the oil and gas policy regulation to avoid what they feared the most: the foreign control over the Norwegian oil industry. The first solution was to develop a normative basis for oil policy by way of the "10 oil commandments".

\subsection{Conclusion}

While genuinely surprised by its oil and gas reserves the Norwegian society coined rapidly an original approach to oil industry based on its previous legal frame enacted to keep hydropower under state control. The international context favoured the Norwegians, as oil companies searched for a stable and predictable country to perform petroleum related activities. Thus, the Norwegian regulatory framework was able to implement initial policy decisions seeking a slow and controlled oil and gas activity, a consistent governmental participation through a national oil company and the creation of a Norwegian supply and service industry.

\section{Norwegian oil constitutionalism and the transition to renewable energy}

As a natural evolution of the previous approach to oil and gas, four innovative policy decisions followed: the "10 oil commandments", the national oil company, the "go slow" policy and the principle of realist sustainability. The " 10 oil commandments", essentially an oil and gas constitution synthetized the Norwegian approach to the petroleum industry while the creation of the national oil company and enactment of "go slow policy" aimed at keeping a tight state control

\footnotetext{
of the project "Innovation, Path-dependency and Policy" (IPP) carried out at the Centre for Technology, Innovation Culture (TIK), University of Oslo 2007 <http://www.sv.uio.no/tik/InnoWP/EngenTIKpaper\%20WPready.pdf $>$ accessed 6 July 2020.

${ }^{100}$ Keto (n 29) 32.

${ }^{101}$ Engen, (n 99 ) 10
} 
over the oil industry and at gaining a strong bargaining power in relation to big international oil companies. That way Norway was able to conduct oil exploration and exploitation according to its values and terms sustainability and protection of the environment. This setting was able to open the road for the introduction of art 110b (later 112) in the Norwegian Constitution, elevating the principle of realistic sustainability to constitutional level. In that way the tradition to protect the environment and exploit resources sustainably was validated and imposed constitutionally, encouraging the transition from oil and gas to other exportable renewable sources of energy related products and services.

\subsection{The 10 oil commandments}

Petroleum had become a central issue in Norwegian politics. ${ }^{102}$ The Parliament's Standing Committee on Industry ${ }^{103}$ proposed a broad framework which would set the petroleum regulatory framework for decades. This progressive policy was likely due to the smart strategy of involving all members of the Storting in the process of drafting. ${ }^{104}$ A stable, predictable, and reliable petroleum regulatory framework was thus created compared to other volatile jurisdictions. That was, and still is today, one of the main advantages of doing oil business in Norway.

In the 1971 White Paper ${ }^{105}$ a veritable oil constitution was enacted, in the form of " 10 oil commandments" 106 containing the petroleum policy statement that would shape future Norwegian oil policy. The commandments stated: ${ }^{107}$

(1) National supervision and control must be ensured for all operations on the NCS.

(2) Petroleum discoveries must be exploited in a way which makes Norway as independent as possible of others for its supplies of crude oil.

\footnotetext{
${ }^{102}$ No (n 18) 47.

${ }^{103}$ Cleary (n 5) 35 .

104 ibid 36.

${ }^{105}$ In the Norwegian legislative system white papers (Meld.St.) are used when future policy issues are submitted to the Storting. These documents do not require a specific decision but are the starting point in drafting resolutions and bills in a later phase.

${ }^{106}$ Bjørn Vidar Lerøen, 10 Commanding Achievements (Norwegian Petroleum Directorate 2010) 1

107 ibid.
} 
(3) New industry will be developed on the basis of Petroleum.

(4) The development of an oil industry must take necessary account of existing industrial activities and the protection of nature and the environment.

(5) Flaring of exploitable gas on the NCS must not be accepted except during brief periods of testing.

(6) Petroleum from the NCS must as a general rule be landed in Norway, except in those cases where socio-political considerations dictate a different solution.

(7) The state must become involved at all appropriate levels and contribute to a coordination of Norwegian interests in Norway's petroleum industry as well as to the creation of an integrated oil community which sets its sights both nationally and internationally.

(8) A state oil company will be established that can look after the government's commercial interests and pursue appropriate collaboration with domestic and foreign oil interests.

(9) A pattern of activities must be selected north of the 62nd parallel which reflects the special socio-political conditions prevailing in that part of the country.

(10) Large Norwegian petroleum discoveries could present new tasks for Norway's foreign policy.

Some of these commandments represented the status-quo, but some would become gamechangers for future dealings, requiring substantial changes to the petroleum regulatory framework. The idea of sustainability and environmental protectionism formed the basis of the fourth and fifth commandments. ${ }^{108}$ The idea of state control over exploration and exploitation planning and the creation of a Norwegian downstream petroleum industry. ${ }^{109}$ The quest for direct Norwegian state

\footnotetext{
${ }^{108}$ Cleary (n 5) 36.

${ }^{109}$ ibid.
} 
participation was declared in the eighth commandment. ${ }^{110}$ The above mentioned "commandments" were innovative in nature as no other petroleum producing country prioritised sustainability and protection of the environment at such length.

However, tight state control over petroleum activities was imperative to make such principle enforceable. Thus, the Government's bargaining power dramatically increased relative to oil companies because of tightly held state control, and participation in oil ventures. ${ }^{111}$ This explains why during the interim licenses of 1971-1972 the Norwegian government was able to increase government participation in various oil ventures. ${ }^{112}$

The Norwegian approach to oil and gas regulation was strongly ideological and sophisticated. ${ }^{113}$ The Norwegian government and Parliament published important policy documents at the very beginning of the oil boom. In contrast, the British, in a pragmatic approach $^{114}$, avoided a policy statement similar to the "10 oil commandments"

\subsection{The national oil company}

The third commandment of the Norwegian "oil constitution" stated the necessity of the creation of a Norwegian oil company: "a new industrial sector should be developed, based on petroleum." ${ }^{116}$ Many countries had already benefited from creating national companies. ${ }^{117}$ These companies ensured that "the greatest possible share of the economic rent ended up in the hands of the state". ${ }^{118}$ A consensus was reached in the Norwegian political elite that Norway must secure participation in the new industry. ${ }^{119}$ The first logical step was to transform a Norwegian company,

\footnotetext{
110 ibid.

${ }^{111}$ Keto (n 29) 32.

${ }^{112}$ Dam (n 97 ) 59.

${ }^{113}$ Noreng (n 18) 27.

114 ibid.

115 ibid.

${ }^{116}$ Innstilling Fra Den Forsterkede Industrikomite Om Undersøkelser Etter Og Utvinning Av Undersjøiske

Petroleumforekomster På Den Norske Kontinentalsokkel [Recommendations from the amplified industry committee on exploration for and exploitation of petroleum resources on the Norwegian Continental Shelf] Innst- S.

[Recommendation to the parliament] no. 294 (1970-71).

${ }^{117}$ United Kingdom: The British Petroleum Company, Italy: Ente Nazionale Idrocarburi and France Essence et Lubrifiants de France.

${ }^{118}$ Cleary (n 5) 39 Ryggvik (n 11) 23.

${ }^{119}$ Ryggvik (n 11) 8.
} 
Norsk Hydro, into the desired entity, as the company was already operating in the North Sea. ${ }^{120}$ The Government tried to transform Norsk Hydro in a national petroleum company by buying its shares in secret. ${ }^{121}$ While the company had considerable expertise in hydropower, it had minor expertise in oil and gas. It was also unsuited ${ }^{122}$ to be a national oil company because Hydro was difficult to control given its particular corporate culture. ${ }^{123}$ In short time it was obvious that the solution would not fulfil the expectations and the need for a brand-new company was born. ${ }^{124}$

The Norwegian institutional model in the field of oil and gas regulation was reformed in $1972^{125}$ when the Storting unanimously voted ${ }^{126}$ for a "tripartite model". First, the Petroleum Ministry was created as being independent from the Industry Department. Second, the Norwegian Petroleum Directorate (NPD) was the new regulatory authority (independent from the Petroleum Ministry) overseeing all petroleum operations on the Norwegian Continental Shelf. ${ }^{127}$ Third, Den Norske Stats Oljeselskap A/S (The Norwegian State Oil Company), later renamed Statoil, was created.

Statoil was created with a dual purpose: first, to pursue state interests, and second, to act as an operator under the supervision of NPD. ${ }^{128}$ The two purposes were complementary as operatorship ensured direct technical control over oil and gas exploration, and exploitation and state participation through the national oil company implied financial and organizational control. In addition to that, there were other expectations from Statoil, such as the control of the pace of extractions, the standardisation of the Norwegian safety requirements for workers and the protection of the environment. ${ }^{129}$ In conclusion, Statoil was expected to affirm its presence in all

\footnotetext{
${ }^{120}$ Cleary (n 5) 39 Ryggvik (n 11) 25.

${ }^{121}$ Ryggvik (n 11) 8.

122 ibid 9.

123 ibid.

${ }^{124}$ Cleary (n 5) 39 and Ryggvik (n 11) 25.

${ }^{125}$ Ryggvik (n 11) 9.

${ }^{126}$ Cleary (n 5) 39.

127 ibid 40.

${ }^{128}$ Ryggvik (n 11) 10.

${ }^{129}$ ibid.
} 
areas of the petroleum industry ${ }^{130}$ as well as to help the creation of a supply/contractor/service industry for the petroleum activities. ${ }^{131}$

Statoil was wholly owned by the government but was independent from it regarding business decisions. ${ }^{132}$ As stated in the 10 oil commandments, Norwegians wanted to ensure that foreign oil investment in Norway was by exception. ${ }^{133}$ This would ensure dominant Norwegian presence in the Norwegian oil sector. Therefore, Statoil's activity was vaguely and broadly defined, granting the company considerable leeway ${ }^{134}$ in being able to perform activities, such as extraction, transportation, and refining, ${ }^{135}$ Statoil could enter into any oil venture on the Norwegian Continental Shelf without paying for the exploration expenditures. Moreover, Statoil executives demanded and obtained seismic data generated by other companies which increased their knowledge and expertise on the Norwegian Continental Shelf. ${ }^{136}$

The reasons for the creation of Statoil were mainly political ${ }^{137}$ and based on the principles of oil constitutionalism that developed the 'go slow' policy, discussed in the next section. This paper contends the economic incentives for creating Statoil were secondary as Norway primarily used Statoil to increase its bargaining power and impose sustainable and environmental measures. Statoil, in addition to regulation and taxation legislation, tighten Norway's control over the petroleum industry. ${ }^{138}$ Clearly, Statoil was not simply established to achieve short-term gains as without such legislative support, Statoil's exploration and exploitation costs would be much higher than that of experienced companies. ${ }^{139}$

\footnotetext{
${ }^{130}$ ibid.

131 ibid.

${ }^{132}$ Dam n (93) 63.

${ }^{133}$ Cleary (n 5) 41 and Lind and Mackay (n 52) 101.

${ }^{134}$ Cleary (n 5) 40 and Lind and Mackay (n 52) 109.

${ }^{135}$ Cleary (n 5) 40.

136 ibid 41.

${ }^{137} \operatorname{Dam}(\mathrm{n} 97) 64$.

${ }^{138}$ ibid.

${ }^{139}$ ibid.
} 
Statoil was formed ${ }^{140}$ by merging Norsk Hydro and Saga Petroleum. ${ }^{141}$ While there was no practical difference between licensing conditions for Statoil and other companies, ${ }^{142}$ the Norwegian government's bargaining power further increased, by minimising or voiding any threat from an oil company to leave the Norwegian Continental Shelf, ${ }^{143}$ as Statoil was able to take over the operation. ${ }^{144}$ Despite identifying huge oil and gas reserves, Norway was concerned of the negative impact of the oil boom. While they feared unwanted economic, environmental, and social effects, they were also aware of the leverage they will have on big foreign oil companies. Thus, they conceived a revolutionary policy, the "go slow" policy.

\subsection{The "go slow" policy}

In June 1974, the Finance Ministry's White Paper, on The Role of Petroleum Activity in Norwegian Society, introduced the idea of a "go slow" policy. The main idea was the emphasis on moderate petroleum development ${ }^{145}$ in order to maximise Norwegian participation in petroleum development and production. ${ }^{146}$ The report was mainly the result of one man's work, Per Schreiner, the planning director at the Ministry of Finance. ${ }^{147}$ He understood that oil income is a special kind of income which could inflict strong macro-economic consequences. ${ }^{148}$ Petter Nore ${ }^{149}$ acknowledged that "It was the first time anyone had globally made the connection between the oil extraction rate and macroeconomic impact in an oil-producing country". ${ }^{150}$ For that reason, petroleum must be managed in a different manner and tight state control must be put into place. ${ }^{151}$ The report also introduced a revolutionary, financial "go slow" policy, which entailed a reduced

\footnotetext{
140 ibid.

141 ibid.

${ }^{142} \operatorname{Dam}(\mathrm{n} 97) 65$.

143 ibid 65.

144 ibid.

${ }^{145}$ Cleary (n 5) 43.

146 ibid 40

${ }^{147}$ Cleary (n 5) 43.

148 ibid.

${ }^{149}$ Petter Nore who was "executive officer Norwegian Ministry of Petroleum and Energy, Oslo, 1978-1981, head of division, 1981-1985, 87-88, senior research fellow Norwegian School Management, 1985-1987, Vice President Saga Petroleum, 1989-2000" and "professor energy economics Norwegian School Management, since 1993, Vice President Norsk Hydro, Sandvika, Norway, since 2000" and also "lecturer international Programme for Petroleum Management and Administration. Member Norwegian Gas Negotiations Committee, 1989, 1993 - 1995" according to Prabook, <https://prabook.com/web/jan petter.nore/473344> accessed 27 February 2020.

${ }^{150}$ Cleary (n 5) 43.

151 ibid.
} 
use of petroleum incomes in order to avoid "inflationary pressures and changes in the patterns of production and settlement." 152

Other countries gained control over their petroleum industry and resources by nationalizing abruptly after the oil crisis. The Norwegian approach helped achieve a similar outcome but avoided the international outcry accompanying nationalization because oil companies were allowed to keep their ownership as long as they subjected themselves to tight Norwegian control. Moreover, the White Paper discussed the necessity for revising taxation policies to increase oil income for Norway.

The report supported the "go slow" policy on several grounds. Firstly, it was a good economic solution for the inflationary pressures generated by oil revenue. ${ }^{153}$ Norway had virtually no unemployment. Thus, a fast-growing petroleum industry would have generated occupational and social issues. ${ }^{154}$ Secondly, resource management ${ }^{155}$ was important as sustainable exploitation of oil and gas was desired while safeguarding the environment and the Norwegian lifestyle. Thirdly, this policy had to be combined with a fast-learning process ${ }^{156}$ of modern petroleum exploration and exploitation techniques, as expertise in the field of oil and gas was desperately needed by Norwegian personnel. Acquiring experience would be a lengthy process, therefore Norway aimed at slower development establish the technical expertise required. Ahead of its time, the Norwegian Government was concerned about the impact of oil on social, regional, educational, and environmental policies considering its ambition to create a "a qualitatively better society ". 157

The report also stated that efficient oversight of petroleum activity required firm, democratic institutions that could exercise control over all aspects of petroleum activity: exploration, rate of extraction, safety and localization. ${ }^{158}$ Specific methods were outlined for the successful implementation of the "go slow" policy, including the "delay in development (build-

\footnotetext{
${ }^{152}$ Noreng (n 18) 49.

${ }^{153}$ Noreng (n 18) 49.

${ }^{154}$ ibid.

${ }^{155}$ ibid.

156 ibid.

157 ibid.

${ }^{158}$ Cleary (n 5) 43.
} 
up) of individual finds" ${ }^{\prime 159}$ which would determine the level of state participation ${ }^{160}$ as oil prices went up. The paper emphasized state control in all phases of petroleum activity: "exploration, production, processing, exports and marketing" ${ }^{\prime 161}$. Private entities, Norwegian or foreign, could be hired to perform specific duties but only exceptionally to exploit oil resources. ${ }^{162}$

In the 1969 second licensing round, only 14 blocks were released, followed in September 1973 by only one license ${ }^{163}$ granted with Norwegian state participation of $50 \%$ by Statoil. ${ }^{164}$ In the third round in 1974, eight blocks were granted. ${ }^{165}$ The Norwegian government realised the prospect of substantial economic benefits by taking their time in developing oil and gas assets was beneficial. ${ }^{166}$ In 1979 the Norwegian government retained nine of the most, promising blocks for Statoil. ${ }^{167}$

There were a few exceptions to the "go slow" policy. One of them was the Brent reservoir solution. Since this reservoir stretched under both countries' sectors (British and Norwegian), the Norwegian government feared that their oil would be lost as the British were already extracting from their sector. ${ }^{168}$ The Norwegian blocks located adjacent to Brent Field (in the United Kingdom Continental Shelf) ${ }^{169}$ were desired by Esso and Shell ${ }^{170}$ but assigned to Statoil. ${ }^{171}$ Statoil lacked experience, and only the big oil companies had the ability for rapid exploration and development. Thus, the Norwegian government secured for Statoil 50\% equity, Mobil (operator) $15 \%$, Esso $10 \%$, Shell 10\%, Conoco 10\%. The remaining 5\% equity was distributed between Saga and other private companies. ${ }^{172}$ Thus, in critical situations, Norway disregarded its "go slow" policy.

\footnotetext{
159 ibid 44, citing and Lind and Mackay (n 128) 31.

160 ibid.

${ }^{161}$ Lind and Mackay (n 54) 101.

162 ibid.

${ }^{163}$ A production license may cover one or more blocks or parts of blocks.

${ }^{164}$ Noreng (n 18) 44.

${ }^{165}$ Lind and Mackay (n 54) 45

166 ibid.

${ }^{167}$ Dam (n 97) 65.

${ }^{168}$ Ibid 60.

${ }^{169}$ Ryggvik (n 11) 10.

170 ibid.

171 ibid.

172 ibid.
} 
The oil policy decision embodied in the "10 oil commandments" and the original "go slow" approach to oil exploration and exploitation were the main precursors of a sustainability driven approach to oil regulatory framework. This later evolved into the principle of realist sustainability and eventually, the transition to renewables.

\subsection{The principle of realist sustainability}

By the spring of 1977, the "go slow" policy was so embedded in the Norwegian oil regulation that when the Government announced the increase of oil activities ${ }^{173}$, a new policy debate emerged, this time on environmental and safety grounds. ${ }^{174}$ The Government justified the increase in production by the mitigation of the effects of the international recession on Norwegian society and the maintenance of wages and general living standards. ${ }^{175}$ Thus, we can say that the "go slow" policy became part not only of the petroleum policy but also part of Norwegian society's view on how to regulate the oil industry.

The "go slow" policy and the entire Norwegian petroleum regulatory framework was a consequence of a tremendous amount of research and analysis with a strong emphasis on the fact that:

"Norwegian oil policy is based on the principle that our petroleum resources belong to the nation and should be developed under full national control as an integral development of the nation as a whole and with due emphasis on the aspect of conservation of the non-renewable resources. "176

Therefore, the white ${ }^{177}$ paper was premised on the idea of achieving a "realist sustainability". This concept evolved in time and was later added to the Norwegian constitution as article 110(b), later as Article 112. ${ }^{178}$

\footnotetext{
173 ibid 56.

174 ibid 57.

175 ibid.

${ }^{176}$ Cleary (n 5) 47 and Eckbo, P.L.' Regulatory Intentions and Realities the Case of the Norwegian Oil Industry' in Barker T. and Brailovsky, V (eds), Oil or Industry? Energy, Industrialisation and Economic Policy in Canada, Mexico, the Netherlands, Norway and the United Kingdom (Academic Press London) 280.

177 Storting, The Role of Petroleum Activity in Norwegian Society (White Paper No 25, 1973-1974).

${ }^{178}$ See discussion below.
} 
In 1977, an explosion occurred on Ekofisk's Bravo platform on the Norwegian Continental Shelf and caused serious damage by spilling at least 120,000 barrels $^{179}$ of oil ${ }^{180}$ into the North Sea. ${ }^{181}$ In response, the operator Phillips was put under the Norwegian State's authority and responsible for the costs of cleaning up the damage. ${ }^{182}$ This explosion had profound and lasting effects on Norwegian oil policy. ${ }^{183}$ The Government postponed exploratory drillings until 1980 and created an independent commission to review the explosion. ${ }^{184}$ The independent commission emphasized the "poor organization and administrative systems for well control maintenance". ${ }^{185}$ As a result, the Norwegian government recommended improvements in the field of personnel training, technical inspections, control, and research in the field of safety and emergency situations. ${ }^{186}$ For Norwegians, this event highlighted the enormous environmental risks the petroleum industry carries.

Slowly the Government increased its control over the oil industry due to increased bargaining power in relation to oil companies based on the "go slow" policy, the state oil company, the accumulation of substantial oil resources, gradual acquisition of experience in oil and gas, and the evolution of the oil market. ${ }^{187}$ Norway was able to impose its national interests. The "go slow" policy signalled that there was no need to develop oil resources quickly, and international oil companies were not able to pressure Norway into disadvantageous agreements. Moreover, in creating Statoil, Norway indicated that if international oil companies are unwilling to accept these conditions, then Statoil will take over the exploitation of oil. Given the desire of international oil companies to reduce its reliance on countries controlled by the OPEC, Norway, despite these investment constraints, was still an attractive destination.

\footnotetext{
${ }^{179}$ There were other opinions that would estimate the quantity to be 3 times more. However, the Norwegian civil service is proverbially honest and is not likely that it would underreport the quantity.

${ }^{180}$ Fischer D, 'A decision analysis of the oil blowout at Bravo Platform', ILASA Research Memorandum RM-78006, (Laxemburg January 1978) 1-2.

${ }^{181}$ Hans Christian Bugge, a National Perspective on the Oil-Blowout Problem in David W Fisher (ed), Managing Technological Accidents: Two Blowouts in the North Sea (International Institute for Applied Systems AnalysisPergamon Press 1982) 113.

${ }^{182}$ Cleary (n 5) 59 and Fischer (n 180) 21.

183 Noreng (n18) 57.

184 ibid.

${ }^{185}$ Bugge (n 181) 113.

186 ibid.

${ }^{187}$ Noreng (n 18) 47.
} 
Norway also benefited ${ }^{188}$ from an informed political base with a highly educated population who feared foreign influence and enjoyed a stable social and political system ${ }^{189}$. Additionally, Norwegians were preoccupied by the protection of the environment and by the concept of sustainability of exploiting oil reserves. ${ }^{190}$ These factors, including pressure from Norwegian society, resulted in art. $110 \mathrm{~b}$ being added to the Norwegian, ensuring sustainability and protection of the environment. The article states:

\begin{abstract}
"Every person has the right to an environment that is conducive to health and to a natural environment whose productivity and diversity are maintained. Natural resources shall be managed on the basis of comprehensive long-term considerations which will safeguard this right for future generations as well [emphasis added]. In order to safeguard their right in accordance with the foregoing paragraph, citizens are entitled to information on the state of the natural environment and on the effects of any encroachment on nature that is planned or carried out. The authorities of the state shall take measures for the implementation of these principles. ",191
\end{abstract}

For a small oil producing nation, these provisions were innovative due to the constitutional endorsement of realist sustainability. The provision was amended and renumbered in 2014 as art. 112 by introducing a duty on the Government to ensure implementation of the principles enshrined in the article: "The authorities of the state shall take measures for the implementation of these principles". ${ }^{192}$

As the protection of the environment became a mainstream topic worldwide, the Norwegian energy sector started to focus on renewable sources of energy as an alternative to oil. This was possible because the state oil company was under strict control by the Norwegian state. Norway used its resources to pursue a transition to renewable sources of energy. The success of

\footnotetext{
188 Jens Evensen, Oversikt over oljepolitiske spørsmål (Industridepartamentet, Oslo, 1971) 12.

${ }^{189}$ Edith Penrose, 'Aspects of Consumer/Producer Relationships in the Oil Industry' in Ragaei El Mallakh and Carl

Mc Guire (eds), U.S. and World energy Resources (ICEED, Boulder, Col., 1977), p 21-9

${ }^{190}$ Cleary (n 5); 47 Eckbo (n 176) 280.

${ }^{191}$ Constitution of the Kingdom of Norway as amended in 2018 [Norway], 17 May $1814 \S 112$ (emphasis added).

192 ibid.
} 
Statoil was determined by the Norwegian regulatory framework and law, which promoted ideals that the company pursued. ${ }^{193}$

Due to its extensive technological experience in oil and gas, Norway was able to innovate in the field of renewable energy. As an example, the state oil company designed and built the world first floating wind farm concept (Hywind) to capture wind energy in waters deeper than 20-50 meters. ${ }^{194}$ The concept was first built by the Norwegian national oil company at industrial scale near the coast of Scotland. At the same time the company became a world leader in carbon capture and storage (CCS). ${ }^{195}$ The process means that carbon dioxide from onshore industries is captured, and then permanently stored at $1000-2000$ metres below the seabed. ${ }^{196}$

To reflect the new approach to realist sustainability, Statoil changed its name to Equinor in 2018. The name combines "equi" the idea of "equal, equality and equilibrium" while "nor" is stating the Norwegian origin. Equinor is set to invest $15-20 \%$ of its total capital expenditures in innovative energy solutions by $2030 .{ }^{197}$

However, investments in renewables sources of energy are costly. The most successful oil fund ever created is the Norwegian Pension Fund Global which will invest only according to strict ethical rules, including the protection of the environment. The Storting encouraged the fund to be invested in unlisted renewable energy infrastructure increasing the cap from 60 billion kroner to 120 billion kroner, which is the maximum percentage permitted by the law. ${ }^{198}$

The Norwegian renewable energy regulatory framework adapts principles from the oil and gas regulation. For example, strict state control and ownership is embedded in the Offshore Renewable Energy Production Act of 4 June 2010. ${ }^{199}$ This Act regulates the production,

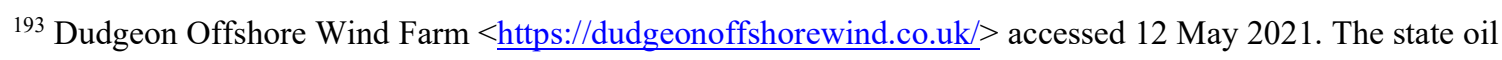
company developed four wind energy projects off the coast of the UK and Germany. It operates the Dudgeon wind farm completed in 2017 and generating 402MW, enough to power more than 410,000 UK households.

${ }^{194}$ Equinor <https://www.equinor.com/en/what-we-do/floating-wind.html> accessed 16 November 2020.

${ }^{195}$ Equinor $<$ https://www.equinor.com/en/magazine/how-we re-making-the-transition.html $>$ accessed 04 July 2020. 196 ibid.

${ }^{197}$ Equinor $<$ https://www.equinor.com/en/news/15mar2018-statoil.html $>$ accessed 04 July 2020.

198 'Norway's wealth fund to double green energy investment cap' (The Local 06.04.2019)

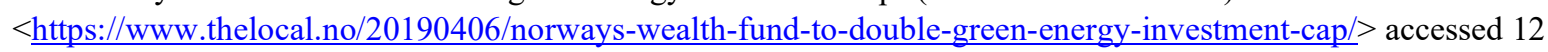
May 2021.

${ }^{199}$ Act Relating to Offshore Renewable Production No 21 of 04 June 2010.
} 
transformation and transmission of energy produced from renewable sources under the principle of public administration and control of the management. ${ }^{200}$ The act states that the identification of an offshore area for renewable energy production is conditioned by compliance with the Environmental Impact Assessment for offshore wind published in January 2013. ${ }^{201}$

In addition, the Ministry of Petroleum and Energy in 2003, based on Directive 2001/77/EC, created a system where guarantees of origin are issued for the energy produced, explaining the origin of the energy produced. ${ }^{202}$ Regulation No 1652 from 14 December 2007 encompasses further rules regarding the issuance of guarantees of origin. This regulation enables a strict accountability of energy sources, the buyer being informed of the origin of the energy being purchased.

The Electricity Certificate $\mathrm{Act}^{203}$, enacted on 24 June 2011 supplemented by Regulation Relating to Electricity Certificates from 16 December 2011 established a joint Swedish and Norwegian electricity certificate market from 1 January 2012 to 2035 to guarantee the production of 26.4 Twh electricity based on renewables sources. ${ }^{204}$ The Electricity Certificate Act was enacted to encourage the use of renewable sources to produce electricity. By issuing an electricity certificate the State guarantees that the electricity to be sold originates in renewable sources. ${ }^{205}$

Following a parliamentary report on energy efficiency, ${ }^{206}$ the Energy Act in 2001 was updated with the creation of an Energy Fund financed partly by end-users and partly by proceeds from a Fund for Climate, Renewable Energy and Energy Conversion. The Energy Fund is managed by a state owned-company, Enova. ${ }^{207}$ The aim is to encourage a more environmentally responsible

200 Martha M. Roggenkamp, Catherine Redgwell, Anit RØnne and Iñigo del Guayo Energy Lay in EuropeNational, EU and International Regulation (Oxford University Press, Third Edition, 2016) 876.

201 ibid.

202 ibid.

${ }^{203}$ Act Relating to Electricity Certificates No 39 of 24 June 2011.

204 ibid.

${ }^{205}$ Energy Facts-Norway 'Electricity Certificates' $<$ https://energifaktanorge.no/en/regulation-of-the-energysector/elsertifikater/\#: :text $=$ The $\% 20$ purpose $\% 20$ of $\% 20$ the $\% 20$ Electricity,of $\% 20$ electricity $\% 20$ from $\% 20$ renewable $\% 20$ sources.\&text $=$ Norwegian $\% 20$ facilities $\% 20$ must $\% 20$ be $\% 20$ in,entitled $\% 20$ to $\% 20$ receive $\% 20$ electricity $\% 20$ cert ificates $>$ accessed 27 February 2021.

${ }^{206}$ Om energipolitikken (St meld No 29 1998-99)

${ }^{207}$ Roggenkamp, Redgwell, Rønne and del Guayo (n 200) 877. 
energy consumption and production in addition to sustaining innovation in the field of sustainable energy technologies. ${ }^{208}$

The above mentioned sustainable environmental measures are a proof a working symbiosis between the process of sustainable exploitation of oil reserves and using the oil income and the oil regulatory framework model to generate a strong sustainable energy production know-how and infrastructure along with regional agreements to implement them.

\subsection{Conclusion}

By enacting the "10 oil commandments" Norway structured its philosophy on controlling the oil and gas industry and implemented its principles regarding sustainability and protection of the environment while maximising income. Both the national oil company and the "go slow" policy were necessary to ensure that the commandments were applicable in oil and gas regulation. This way it was possible to impose the principle of realist sustainability on the oil industry from the early petroleum regulation phase until it was codified in the constitution. The petroleum regulatory framework evolved around this principle paving the road for the slow process of shifting from oil to renewables. Norway is making huge progress in the field of renewables and protection of the environment, not being matched by any other oil producing nation, but the process is slow and full of controversies.

\section{Realist sustainability and its discontents: People vs. Arctic}

Despite being a cohesive society and with a relatively strong political consensus favouring Arctic oil exploration, Norwegians question the destruction of previously untouched natural environment. ${ }^{209}$ Thus, on 18 October 2016, Nature and Youth and Greenpeace (the main plaintiffs) and Friend of the Earth Norway and The Grandparents Climate Campaign (as co-plaintiffs) sued the Norwegian government on extending oil exploration in the Barents Sea. The case was triggered by two events from June 2016: the ratification of the Paris agreement and the award of the first licenses in the Arctic.

\footnotetext{
${ }^{208}$ Government of Norway, ENOVA < https://www.regjeringen.no/en/dep/kld/organisation/Subordinateagencies/enova/id2599611/> accessed 27 February 2021.

${ }^{209}$ Cleary (n 5) 164.
} 
The legal action is based on article 112 of the Norwegian Constitution. ${ }^{210}$ The plaintiffs argue that the Government has an active duty to safeguard the environment but failed to abide by the duty to safeguard the environment by allowing oil drilling in the Arctic. In 2018, the Oslo District Court held that article 112 of the Constitution is a provision conferring rights. ${ }^{211}$ However the court ruled against the plaintiffs because "[e]missions of $\mathrm{CO} 2$ abroad from oil and gas exported from Norway are irrelevant when assessing whether the Decision entails a violation of Article 112." 212 Moreover, the court found the supervision procedure regarding compliance with the Paris Agreement provisions satisfactory for fulfilling the constitutional duty of the Government "to take measures" for the preservation of the environment.

In 2020, the Borgarting Court of Appeal affirmed the District Court's decision ruling ${ }^{213}$ with one notable exception. The appeal judgment affirmed that art. 112 of the Constitution is applicable even for the emissions from the combustion of oil and gas after export. This finding is a very original approach to the legal issues discussed in the case and holds important consequences as Norway is the seventh largest exporter of oil- and gas-related emissions ${ }^{214}$ in the world. While Norway has extremely low levels of internal emissions by encouraging electrical cars and by producing electricity mainly by hydropower plants, Norway's emissions from the exported oil and gas is 10 times greater than Norway's internal emissions. ${ }^{215}$

\footnotetext{
${ }^{210}$ Stortinget- official version of the Norwegian Constitution:

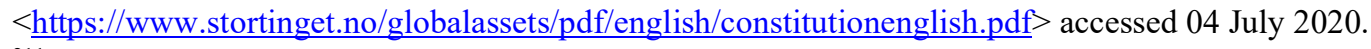

${ }^{211}$ Oslo District Court, case nr 16-166674TVI-OTIR/06 Judgment, $<\underline{\text { http://blogs2.law.columbia.edu/climate-change- }}$ litigation/wp-content/uploads/sites/16/non-us-case-documents/2018/20180104_HR-2020-846-J_judgment-1.pdf $>$ accessed 25 October 2020

212 ibid.

${ }^{213}$ Borgarting Court of Appeal, case nr 18-060499ASD-BORG/03, $<\underline{\text { http://blogs2.law.columbia.edu/climate-change-litigation/wp-content/uploads/sites/16/non-us-case- }}$ documents/2020/20200123 HR-2020-846-J judgment.pdf $>$ accessed 25 October 2020.

214 'The Sky's Limit Norway: Why Norway Should Lead the Way in a Managed Decline of Oil and Gas Extraction' Oil Change International $<$ http://priceofoil.org/2017/08/09/the-skys-limit-norway-why-norway-should-lead-theway-in-a-managed-decline-of-oil-and-gas-

extraction/\#: : text=Norway $\% 20$ is $\% 20$ the $\% 20$ world's $\% 20$ seventh,is $\% 20$ in $\% 20$ currently $\% 20$ operating $\% 20$ fields.\&te $\mathrm{xt}=$ not $\% 20 \mathrm{in} \% 20$ line $\% 20$ with $\% 20$ the,to $\% 20$ achieve $\% 20$ the $\% 20$ Paris $\% 20$ goals $>$ accessed 25 October 2020.

${ }^{215}$ Naturvernforbundet 10 common claims about Norwegian oil and gas, $<$ https://naturvernforbundet.no/energy/10common-claims-about-norwegian-oil-and-gas-article34106-

2020988.html\#: :text=The\%20burning\%20of\%20Norwegian\%20oil\%20and\%20gas\%20emits\%20around $\% 20500$,ti mes\%20the \%20nation's\%20emissions\%20total > accessed 25 October 2020.
} 
Nonetheless, the Court of Appeal held that the Government has a high degree of discretion when fulfilling its art. 112 obligations. Thus, the plaintiffs were not able to prove any violation under the article. The Borgarting Court of Appeal decision was appealed, and on 20 April 2020, the Supreme Court of Norway granted leave to appeal. ${ }^{216}$

On appeal to the Supreme Court, the plaintiffs emphasized three main arguments to support their contention that the licenses granted in the Barents Sea are invalid. ${ }^{217}$ The first is based on art. 112 of the Norwegian Constitution, stating that the Government should act to safeguard the right to a clean and healthy environment. Moreover, the exploited Arctic oil will generate more emissions which would undermine the Paris Agreement provisions. ${ }^{218}$ The plaintiffs were encouraged by the fact that both the District Court and Appeal Court interpreted the constitutional provisions as granting rights but were discontent with the "large margin of discretion" granted to the Norwegian State. Here lays the most notable difficulty for the plaintiffs, namely, to connect the idea of licensing and oil drilling in the Arctic with the right enshrined in art. 112.

The second argument was based on European Convention of Human Rights and stated that the granted licenses will limit basic human rights (the right to life, to right to private and family life). ${ }^{219}$ While the European Court of Human Rights has never itself linked climate issues with human rights, there is national jurisprudence that does. The plaintiffs relied extensively on the Urgenda $^{220}$ case from the Netherlands. In this case, the Dutch Supreme Court upheld a decision from a Hague Court requiring the Government to reduce emissions based on the Government's duties to protect basic human rights. The human rights argument is especially relevant to the Sami people ${ }^{221}$ who presumably will suffer disproportionally compared to other groups in Norway. The third main argument was based on the claim that the Government grossly overestimated the

\footnotetext{
${ }^{216}$ ibid.

${ }^{217}$ Arctic Dialogues - Climate Change Litigation in the Arctic: Perspectives on recent cases

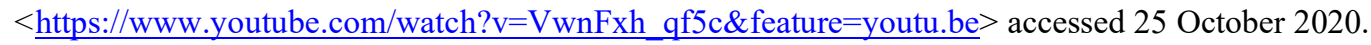

218 ibid.

219 ibid.

${ }^{220}$ Urgenda Foundation v. State of the Netherlands [2015] HAZA C/09/00456689.

${ }^{221}$ The Sami is an indigenous people of Finno-Ugric origin living in northern parts of Norway, Sweden, Finland and Russia. Patrik Lantto 'Borders, citizenship and change: the case of the Sami people1751-2008' (2010) Citizenship Studies, 14:5, 543-556, DOI: 10.1080/13621025.2010.506709.
} 
potential profit from the Barents Sea oil, thus committing procedural errors in granting the licenses. ${ }^{222}$

This case demonstrates a conflict at the constitutional level between climate goals and the sustainable development of oil and gas. It could be helpful to recall the concept of 'realist sustainability' used by Norway to shape its petroleum policy. Art. 112 is the embodiment of the Norwegian approach aiming at balancing the sustainable process of exploration and exploitation of oil with the effort to safeguard the environment. Thus, this paper argues that "realist sustainability" is taking shape from the constitutional text. According to this principle the protection of the environment and the sustainable exploitation of natural resources function as the two sides.

The concept has worked for years in Norway and implies three main characteristics. Firstly, exploitation of natural resources (in this case oil and gas) occurs in a sustainable manner with an aim to shift to renewables. The second is that the protection of the environment is very important and many decisions regarding oil and gas are subject their environmental impact. The third is not explicitly stated but is a consequence of the previous two characteristics: continued exploration and exploitation of oil and gas is required to finance the transition to renewable sources of energy. This is because public support for renewables will only last if there is a strong welfare system.

In late 2020, the Norwegian Supreme Court ruled against the appellants and stated that art. 112 of the Norwegian Constitution is only applicable in Norway. Thus, art. 112 is only applicable exceptionally to emissions generated by burning Norwegian oil in foreign jurisdictions. ${ }^{223}$ The Court also noted that art. 112 does not grant individual rights to challenge petroleum policy in court. While the judgment is complex, it confirms the Norwegian commitment to the principle of realist sustainability. The concepts of sustainability and protection of the environment are considered by the Court the foundation of the Norwegian oil policy. Further, the judgement explains that safety mechanisms designed to assess the environmental impact of oil

\footnotetext{
${ }^{222}$ Arctic Dialogues (n 217).

${ }^{223}$ The Supreme Court of Norway, case nr. HR-2020-846-J, (sak nr. 20-051052SIV-HRET)
} 
exploration and exploitation are sufficient to fulfil the Government's duty to care for the environment. 224

\section{Conclusion}

A coherent legal ideology focused on sustainability provided the foundation for the Norwegian petroleum regulatory framework, and the later enactment of art. 112 (former Article 110b) of the Norwegian Constitution in 1992. From the beginning, the Norwegian concept was focused on imposing the principle of sustainability on petroleum operations in the Norwegian Continental Shelf. Realising that big oil companies would prioritise short-term interests over sustainability, Norway imposed strong state control. However, they also needed to increase their bargaining power in relation to the oil companies operating on the continental shelf. Thus, enacted the "go slow" policy, and created the national oil company, Statoil. The "go slow" policy conveyed to the big international oil companies that Norway does not necessarily need an oil boom and also that Norway is fighting the resource curse by avoining to become excessively dependent on oil. Moreover the increased bargaining power enabled by this policy granted the Norwegian negotiators the ability to oppose any unwanted terms proposed by international oil companies, being enough to mention that Statoil can take over the operations, which eventually happened to some extent.

When evaluating the Norwegian model, it is important to consider the context of the 1970s as the oil and gas market appears very different from the 1970s. Norway was the first state to be deeply invest in the idea of sustainability among all the oil nations. Their motivation was complex as they feared excessively long periods of economic growth and high levels of inflation, and also aimed to avoid negative social impacts. A long-term approach instead ensured a steady stream of income that greatly assisted with the growth of the welfare state.

The Norwegian solution was very original and very difficult to be emulated for several reasons: Firstly, Norway from the beginning enacted an oil constitution in order have a standard reference for all subsequent petroleum regulations. One should note that the principles found in the 10 oil commandments are strictly respected to date. Today, there is almost no oil producing

${ }^{224}$ Ibid. 
nation that has entrenched the idea of sustainability into the development of its oil industry from the commencement of oil exploration and exploitation, other than at a rhetorical level. The second argument would be that oil is an industry full of temptations related to short-term growth; when oil is found, sustainability falls behind. The Norwegians were ready to slow their oil production to achieve their objectives. In comparison, there are few countries other where there is sufficiently strong political will to do the same. Thirdly, integral to the Norwegian model is a strong dedicated and efficient civil service which collaborated with the executive (ministers) exceptionally to develop a strong Norwegian petroleum industry and maintain a strict control over oil reserves in the Norwegian continental shelf. 